\title{
PEMBUATAN VIDEO DAN BANNER WEB SEBAGAI MEDIA PROMOSI DI PUSAT PENELITIAN DAN PENGEMBANGAN HORTIKULTURA
}

\section{(Making Video and Web Banner as Promotional Media in Horticultural Research and Development Center)}

\author{
HARVINI AL MEITAVIA ${ }^{1}$, GEMA PARASTI MINDARA ${ }^{2}$, ANDY PRAMURJADI ${ }^{3}$ \\ ${ }^{1}$ Manajemen Informatika Sekolah Vokasi IPB, Jl. Kumbang No. 14, Bogor \\ ${ }^{2}$ Sekolah Vokasi IPB, Jl. Kumbang No. 14, Bogor \\ ${ }^{3}$ Pusat Penelitian dan Pengembangan Hortikultura Jl. Tentara Pelajar No. $3 \mathrm{C}$ Kampus Penelitian \\ Pertanian Cimanggu, Bogor
}

Email : harvinimeitavia@gmail.com,gemaparasti@gmail.com, a.pramurjadi@gmail.com

\begin{abstract}
Horticulture Research and Development Center is research center under the Research and Development Agency Agriculture which is located in Bogor, West Java. Horticulture Research and Development Center has four research centers, there are Vegetable Crops Research Institute (Balitsa), Tropical Fruit Research (Tropical Balitbu), Plant Research Institute (Balithi), and Research Institute for Citrus and Subtropical Fruits (Balitjestro). Each hall has a trial garden that is useful as a medium planting for variety plants developed by the Horticultural Research and Development Center. The results of fertilization of plants with certain varieties will be managed by UPBS or Seed Source Management Unit. The Field Work Practices is overseen by the Cooperation Division and Utilization of Agricultural Products. This activity produces products multimedia in the form of a web banner and company profile video for the Horticulture Research and Development Center. Making videos and web banners using different method. There are four methods used in the field of graphic design studies ie stages, concepts, material collection, design and implementation, and testing. The method used in the field of video studies consists of three stages that is, pre-production, production, and postproduction.

Key words: Horticulture Research and Development Center, Cooperation Division and Utilization of Agricultural Products, research center, graphic design, company profile video.
\end{abstract}

\section{ABSTRAK}

Pusat Penelitian dan Pengembangan Hortikultura merupakan salah satu pusat penelitian yang berada dibawah Badan Penelitian dan Pengembangan Pertanian yang terletak di Bogor Jawa Barat. Puslitbang Hortikultura memiliki empat balai penelitian, yaitu Balai Penelitian Tanaman Sayuran (Balitsa), Balai Penelitian Tanaman Buah Tropika (Balitbu Tropika), Balai Penelitian Tanaman Hias (Balithi), dan Balai Penelitian Tanaman Jeruk dan Buah Subtropika (Balitjestro). Setiap balai memiliki kebun percobaan yang berguna sebagai media tanam untuk tanaman varietas yang dikembangkan oleh Puslitbang Hortikultura. 
Hasil pembuahan tanaman dengan varietas tertentu akan dikelola oleh UPBS atau Unit Pengelola Benih Sumber. Kegiatan Praktik Kerja Lapang (PKL) ini dibawahi oleh Divisi Kerjasama dan Pendayagunaan Hasil Pertanian. Kegiatan ini menghasilkan produk multimedia berupa banner web dan video company profile Puslitbang Hortikultura. Pembuatan video dan banner web menggunakan metode kajian yang berbeda. Metode yang digunakan pada bidang kajian desain grafis terdapat empat tahapan yaitu, konsep, pengumpulan bahan, desain dan implementasi, dan pengujian. Metode yang digunakan pada bidang kajian video terdapat tiga tahapan yaitu, pra produksi, produksi, dan pasca produksi.

Kata kunci: Puslitbang Hortikultura, Divisi Kerjasama dan Pendayagunaan Hasil Pertanian, balai penelitian, desain grafis, dan video company profile.

\section{PENDAHULUAN}

Pusat Penelitian dan Pengembangan Hortikultura merupakan salah satu pusat penelitian yang berada dibawah Badan Penelitian dan Pengembangan Pertanian yang terletak di Bogor Jawa Barat dan berdiri sejak tahun 1984. Pusat Penelitian dan Pengembangan Hortikultura atau biasa disingkat Puslitbang Hortikultura merupakan unit kerja di bawah Badan Litbang Pertanian atau Balitbangtan yang diberi mandat melaksanakan penelitian dan pengembangan komoditas hortikultura.

Puslitbang Hortikultura memiliki empat balai penelitian, yaitu Balai Penelitian Tanaman Sayuran (Balitsa), Balai Penelitian Tanaman Buah Tropika (Balitbu Tropika), Balai Penelitian Tanaman Hias (Balithi), dan Balai Penelitian Tanaman Jeruk dan Buah Subtropika (Balitjestro). Setiap balai memiliki kebun percobaan yang berguna sebagai media tanam untuk tanaman varietas yang dikembangkan oleh Puslitbang Hortikultura. Hasil pembuahan tanaman dengan varietas tertentu akan dikelola oleh UPBS atau Unit Pengelola Benih Sumber.

Banyak hasil hortikultura dari berbagai balai penelitian yang kurang diketahui masyarakat luas, sehingga membuat Puslitbang Hortikultura kurang dikenal di kalangan masyarakat. Salah satu upaya yang dilakukan adalah dengan membuat banner web sebagai media informasi yang ditampilkan pada situs web Puslitbang Hortikultura yaitu http://hortikultura.litbang.pertanian.go.id/ yang berisikan informasi produk, layanan Hortikultura, dan informasi lainnya serta membuat video company profile dari Puslitbang Hortikultura sebagai media promosi serta informasi kepada audience. Pembuatan video ini merupakan solusi untuk penyebaran informasi Puslitbang Hortikultura secara luas mengenai lokasi, gedung, jasa pelayanan, varietas unggul, kerjasama yang telah dilakukan, serta informasi lain yang belum diketahui oleh masyarakat luas.

Kegiatan Praktik Kerja Lapang (PKL) ini dibawahi oleh Divisi Kerjasama dan Pendayagunaan Hasil Pertanian. Kegiatan ini menghasilkan produk multimedia berupa lima buah banner web dengan tema Analisis Kebijakan Hortikultura, Pengelolaan Tanaman Terpadu Cabai, Pengelolaan Tanaman Terpadu Bawang Merah, Asian Food and Agriculture Cooperation Initiative, dan Kalender Buah Nasional, serta menghasilkan satu buah video company profile Puslitbang Hortikultura. Tujuan dari pembuatan produk multimedia di Puslitbang Hortikultura 
yaitu:

1. Membuat desain grafis untuk Puslitbang Hortikultura berupa lima buah banner web.

2. Membuat video company profile untuk Puslitbang Hortikultura.

\section{METODE PENELITIAN}

\section{Metode Penelitian Desain Grafis}

Pembuatan desain grafis dalam kegiatan Praktik Kerja Lapang (PKL) ini adalah pembuatan lima buah banner web yaitu, banner web Analisis Kebijakan Hortikultura, banner web Pengelolaan Tanaman Terpadu Cabai, banner web Pengelolaan Tanaman Terpadu Bawang Merah, banner web Asian Food and Agriculture Cooperation Initiative, dan banner web Kalender Buah Nasional. Metode yang digunakan dalam pembuatan desain ini yaitu melalui empat tahapan. Tahapan-tahapan tersebut adalah konsep, pengumpulan bahan, desain dan implementasi, dan pengujian. Tahapan metode bidang kajian desain grafis dapat dilihat pada Gambar 1.

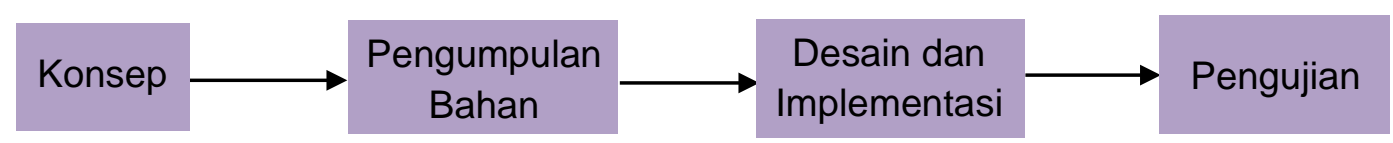

Gambar 1 Metode Bidang Kajian Desain Grafis

\section{Konsep}

Konsep yang dibahas untuk pembuatan banner web yaitu desain yang tidak terlalu menggunakan banyak warna, informasi yang disampaikan singkat tetapi jelas, dan dapat di mengerti oleh pengunjung web Puslitbang Hortikultura. Banner web yang dibuat berukuran 1100 x 460 point dengan foto produk dan sedikit informasi didalamnya.

\section{Pengumpulan Bahan}

Pengumpulan bahan untuk memperoleh informasi dari Puslitbang Hortikultura mengenai informasi yang akan disampaikan pada produk desain grafis. Bahan yang dibutuhkan berupa foto varietas, logo Kementerian Pertanian, logo Agro Inovasi, logo AFACI, serta informasi yang akan disampaikan pada banner web.

3. Desain dan implementasi

Pada tahap ini semua bahan yang sudah dikumpulkan akan didesain sehingga menjadi produk yang bisa dilihat dan audiens bisa menerima informasi. Desain banner web yang dihasilkan sebanyak lima buah yaitu, banner web Analisis Kebijakan Hortikultura, banner web Pengelolaan Tanaman Terpadu Cabai, banner web Pengelolaan Tanaman Terpadu Bawang Merah, banner web Asian Food and Agriculture Cooperation Initiative, dan banner web Kalender Buah Nasional

\section{Pengujian}

Banner web yang telah dibuat kemudian dilakukan pengujian. Pengujian 
yang digunakan adalah pengujian alpha dan pengujian beta. Pengujian alpa atau alpha testing yaitu pengujian yang dilakukan oleh pihak internal sebelum didistribusikan kepada pihak eksternal. Kemudian pengujian beta atau beta testing yaitu pengujian yang dilakukan oleh pihak eksternal perusahaan. Pengujian beta dilakukan dengan cara membuat survei dengan pertanyaan yang menyangkut dengan informasi yang disampaikan dan warna yang digunakan pada banner web.

\section{Metode Penelitian Video}

Metode yang digunakan dalam pembuatan video ini melalui tiga tahapan, antara lain pra produksi, produksi, dan pasca produksi. Tahapan metode bidang kajian video dapat dilihat pada Gambar 2.

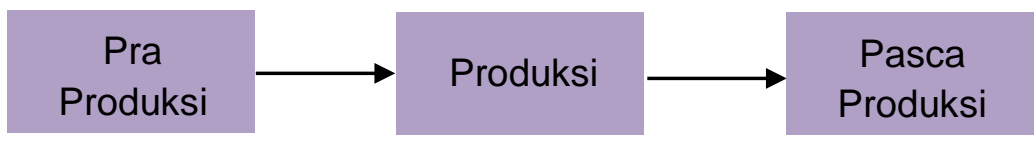

Gambar 2 Metode Bidang Kajian Video

\section{Pra Produksi}

Menurut Hendi Hendratman (2017) pra produksi adalah tahap sebelum video diproduksi secara nyata. Tahap pra produksi adalah tahap awal persiapan segala kebutuhan sebelum memasuki tahapan produksi. Tahap ini memudahkan untuk tahapan selanjutnya yaitu produksi. Tahap produksi meliputi konsep, pengumpulan data, membuat naskah, dan membuat storyboard.

\section{a. Konsep}

Proses konsep adalah proses pembuatan ide atau gagasan yang akan diterapkan pada video yang akan dibuat. Konsep yang dibahas dalam pembuatan video ini bersifat simple dan non formal agar audience tidak bosan melihat video yang ditampilkan. Video yang akan dihasilkan berdurasi 3-4 menit dengan ukuran $1920 \times 1080$ dan format video mp4.

\section{b. Pengumpulan data}

Pengumpulan data bertujuan untuk memperkuat informasi yang disampaikan pada video. Pengumpulan data dilakukan pada saat berdiskusi dengan pembimbing lapang. Data yang dikumpulkan berupa teks, foto, dan video. Video yang dikumpulkan berupa satu buah video gedung yang diambil menggunakan drone, satu buah video gedung Balitbu Tropika, dan satu buah video kebun percobaan yang diambil menggunakan drone.

\section{c. Membuat Naskah}

Membuat naskah yang sesuai pada konsep yang telah dibahas sebelumnya dan ditentukan berdasarkan kesepakatan bersama dengan pembimbing lapang. Naskah dibuat sebagai acuan untuk membuat storyboard serta voice over sebagai penjelas video.

\section{d. Membuat Storyboard}

Tahap selanjutnya adalah pembuatan storyboard. Storyboard merupakan 
rangkaian gambar sketsa yang menggambarkan alur cerita dan bentuk lanjutan dari naskah cerita yang sudah dikembangkan dan diimplementasikan dalam bentuk gambar. Pada storyboard menampilkan durasi dari setiap video yang akan diimplementasikan.

\section{Produksi}

Menurut Hendi Hendratman (2017) produksi adalah tahap pengambilan data yang dibutuhkan sesuai script dan storyboard. Tahap produksi pada video company profile meliputi pengambilan gambar atau video shooting sesuai dengan naskah, persiapan data atau footage preparation, pengambilan suara meliputi suara manusia dan musik latar, serta pemilihan typeface yang digunakan untuk infografis yang ditampilkan pada video.

\section{Pasca Produksi}

Menurut Hendi Hendratman (2017) pasca produksi adalah tahap mengolah data-data yang diambil di tahap produksi sehingga bisa menjadi bahan final yang siap untuk diedarkan. Tahap ini merupakan tahap akhir serta penyempurnaan dalam video yang akan dihasilkan. Tahap pasca produksi juga meliputi revisi yang dilakukan oleh pembimbing lapangan.

\section{a. Olah digital video atau video editing}

Tahap olah digital video atau video editing yaitu tahap penggabungan data gambar, video, audio, dan teks yang sudah direncanakan. Video yang sudah diambil pada tahap produksi kemudian akan diolah pada tahap pasca produksi.

\section{b. Rendering}

Rendering video yaitu proses mengubah file projek menjadi sebuah file yang dapat dijalankan di media lain dengan format video pada umumnya. Proses rendering pada video company profile menghasilkan video dengan ukuran resolusi layar FullHD yaitu 1920 x 1080 dan ekstensi file mp4.

\section{c. Penggandaan Video}

Video yang telah selesai diolah kemudia diduplikasi ke berbagai media seperti DVD, flashdisk, dan harddisk. Video yang telah digandakan kemudian diserahkan kepada pembimbing lapang untuk dievaluasi berdasarkan konsep yang sudah dibahas sebelumnya.

\section{d. Evaluasi}

Menurut $\mathrm{KBBI}$, evaluasi adalah proses untuk menemukan nilai layanan informasi atau produk sesuai dengan kebutuhan konsumen atau pengguna. Evaluasi pada video company profile ini dilakukan oleh pembimbing lapang sesuai dengan konsep yang sudah dibahas sebelumnya.

\section{e. Revisi}

Revisi pada video company profile dilakukan berdasarkan dengan evaluasi yang telah diberikan oleh pembimbing lapang. Hasil revisi yang telah dilakukan akan didistribusikan kepada pembimbing lapang dan Kepala Bidang Kerjasama 
Pendayagunaan Hasil Pertanian.

\section{f. Distribusi}

Video yang dievaluasi dan direvisi akan didistribusikan kepada pembimbing lapang dalam bentuk video berekstensi mp4. Video yang sudah didistribusikan akan ditampilkan pada sebuah televisi yang terletak di front office Puslitbang Hortikultura.

\section{g. Pengujian}

Pengujian yang dilakukan adalah pengujian alpa dan pengujian beta. Pengujian alpa adalah pengujian yang berdasarkan pihal internal yaitu pembimbing lapang. Pengujian beta adalah pengujian yang dilakukan oleh pihak eksternal perusahaan dengan membuat survei berdasarkan target audience yang sudah ditentukan.

\section{HASIL DAN PEMBAHASAN}

\section{Hasil dan Pembahasan Desain Grafis}

Pembuatan desain grafis banner web bertujuan untuk memberikan informasi tentang inovasi produk unggulan hortikultura yang telah dikembangkan. Metode yang digunakan dalam pembuatan desain ini melalui empat tahapan.

\section{Konsep}

Konsep yang dibahas untuk pembuatan banner web yaitu desain yang tidak terlalu menggunakan banyak warna, informasi yang disampaikan singkat tetapi jelas, dan dapat di mengerti oleh pengunjung web Puslitbang Hortikultura. Banner web yang dibuat berukuran $1100 \times 460$ point dengan foto produk dan sedikit informasi didalamnya. Hasil banner web akan dipublikasikan pada situs web Puslitbang Hortikultura.

\section{Pengumpulan Bahan}

Pengumpulan bahan untuk memperoleh informasi dari Puslitbang Hortikultura mengenai informasi yang akan disampaikan pada produk desain grafis. Bahan yang dibutuhkan berupa foto varietas, logo Kementerian Pertanian, logo Agro Inovasi, logo AFACI, serta informasi yang akan disampaikan pada banner web. Tahap ini dilakukan untuk mempermudah proses desain produk pada tahap desain sesuai dengan konsep yang sudah ditentukan.

\section{Desain dan implementasi}

Pada tahap ini semua bahan yang sudah dikumpulkan akan didesain sehingga menjadi produk yang bisa dilihat dan audiens bisa menerima informasi. Desain banner web yang dihasilkan sebanyak lima buah yaitu, banner web Analisis Kebijakan Hortikultura, banner web Pengelolaan Tanaman Terpadu Cabai, banner web Pengelolaan Tanaman Terpadu Bawang Merah, banner web Asian Food and Agriculture Cooperation Initiative, dan banner web Kalender Buah Nasional. Pada tahap desain, banner web di desain menggunakan Adobe Illustrator CC 2017. 
Hasil desain dan implementasi banner web terdapat lima buah yaitu banner web Analisis Kebijakan Hortikultura, banner web Pengelolaan Tanaman Terpadu Cabai, banner web Pengelolaan Tanaman Terpadu Bawang Merah, banner web Asian Food and Agriculture Cooperation Initiative, dan banner web Kalender Buah Nasional. Hasil desain dan implementasi banner web dapat dilihat pada Gambar 3 sampai Gambar 7.

a. Desain dan implementasi banner web pertama dengan tulisan "Analisis Kebijakan Hortikultura" beserta informasi yang disampaikan dan foto produk hortikultura ditujukan untuk menginformasikan audiens tentang penyebaran Analisis Kebijakan Hortikultura. Hasil desain banner web ANJAK dapat dilihat pada Gambar 3.

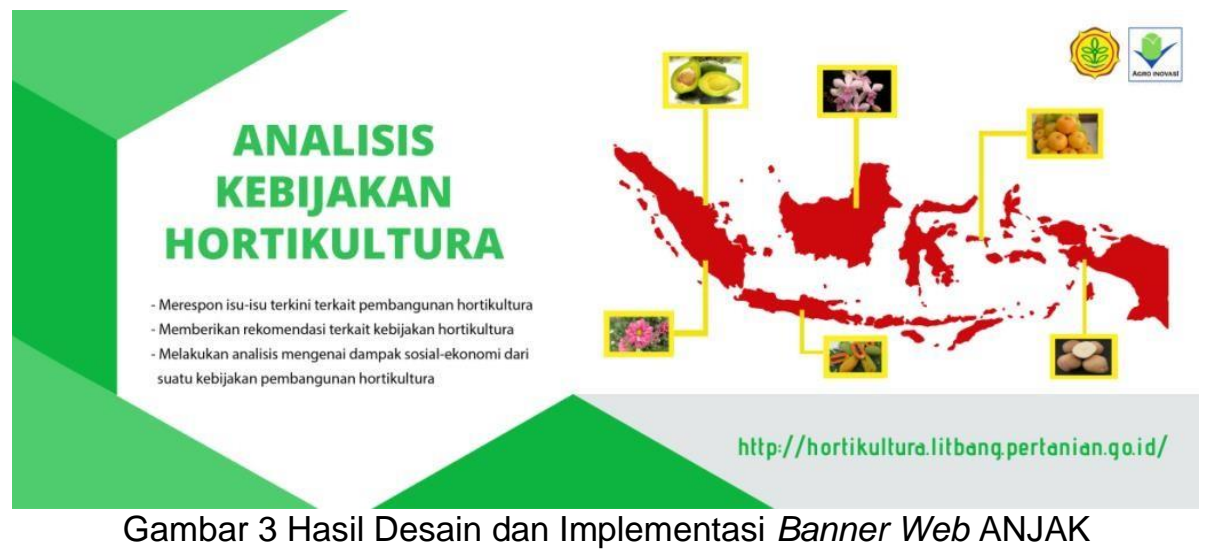

b. Desain dan implementasi banner web kedua dengan tulisan "Pengelolaan Tanaman Terpadu Cabai" beserta informasi yang disampaikan ditujukan untuk menginformasikan audiens tentang pengelolaan tanaman cabai yang dilakukan oleh Puslitbang Hortikultura. Hasil desain banner web PTT Cabai dapat dilihat pada Gambar 4.

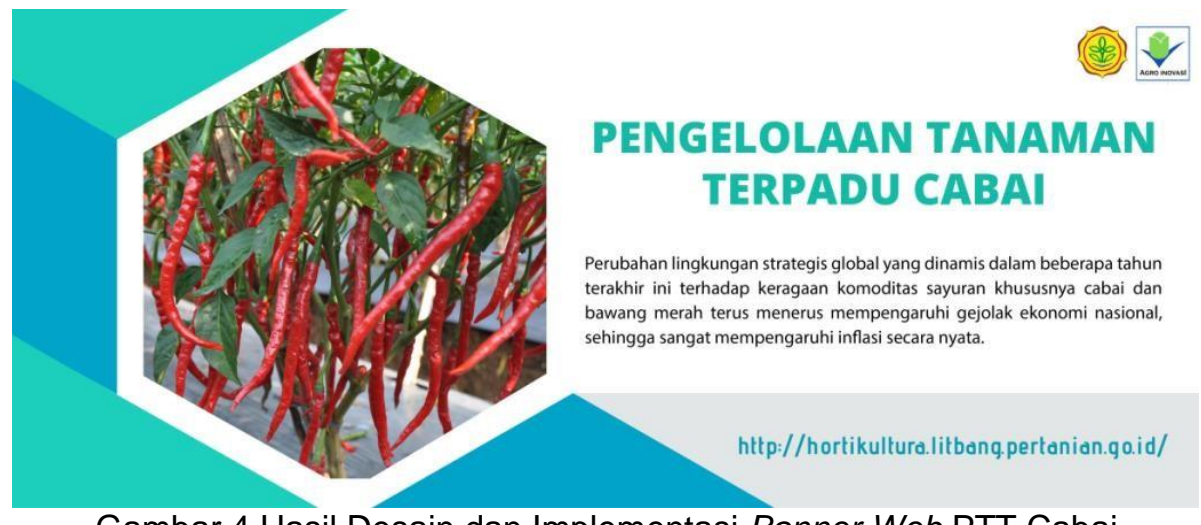

Gambar 4 Hasil Desain dan Implementasi Banner Web PTT Cabai

c. Desain dan implementasi banner web ketiga dengan Tulisan "Pengelolaan Tanaman Terpadu Bawang Merah" beserta informasi yang disampaikan ditujukan untuk menginformasikan audiens tentang pengelolaan tanaman bawang merah yang dilakukan oleh Puslitbang Hortikultura. Hasil desain dan implementasi banner web Pengelolaan Tanaman Terpadu Bawang Merah dapat dilihat pada Gambar 5. 


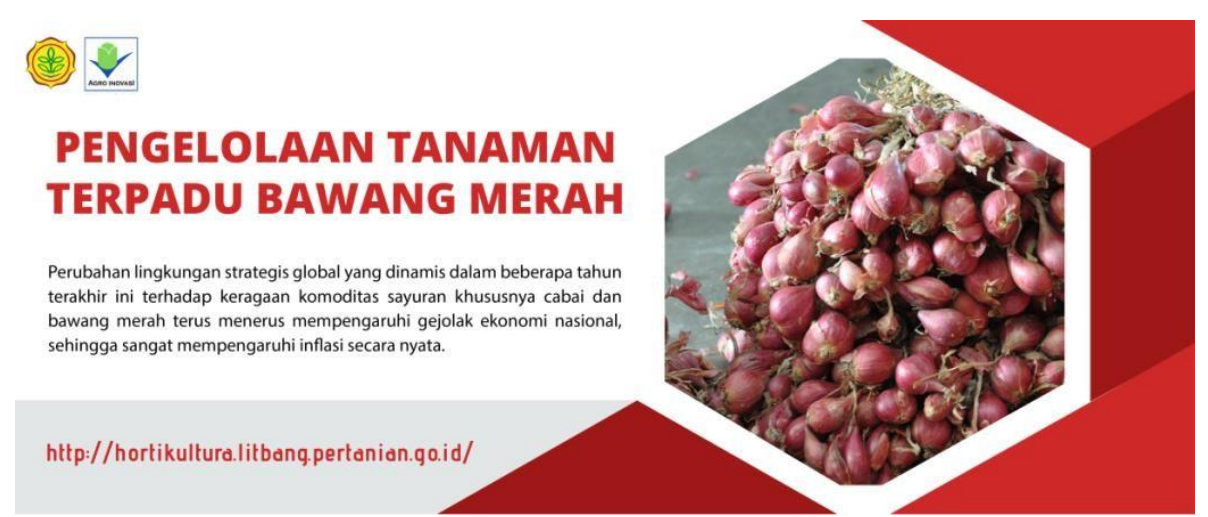

Gambar 5 Hasil Desain dan Implementasi Banner Web PTT Bawang Merah

d. Desain dan implementasi banner web keempat dengan Tulisan "Asian Food and Agriculture Cooperation Initiative" beserta informasi yang disampaikan ditujukan untuk menginformasikan audiens tentang kerjasama Puslitbang Hortikultura dan AFACl. Hasil desain dan implementasi banner web Pengelolaan Asian Food and Agriculture Cooperation Initiative dapat dilihat pada Gambar 6.

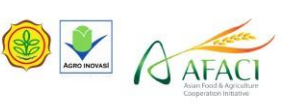

Pusat Penelitian dan Pengembangan Hortikultura bekerjasama dengan AFACI telah mendorong implementasi GAP (Good Agricultural Practices) pada tanaman hortikultura. GAP adalah teknis penerapan sistem sertifikasi proses
produksi pertanian yang menggunakan teknologi maju ramah lingkungan dan berkelanjutan, sehingga produk panen aman dikonsumsi, dan dapat memberikan keuntungan ekonomi bagi petani.
ASIAN FOOD \& AGRICULTURE COOPERATION INITIATIVE

\section{http://hortikultura.litbang.pertanian.qo.id/}

Gambar 6 Hasil Desain dan Implementasi Banner Web AFACI

e. Desain dan implementasi banner web kelima dengan Tulisan "Kalender Buah Nasional" beserta informasi yang disampaikan ditujukan untuk menginformasikan audiens tentang kegiatan pada kalender buah nasional. Hasil desain banner web AFACI dapat dilihat pada Gambar 7.

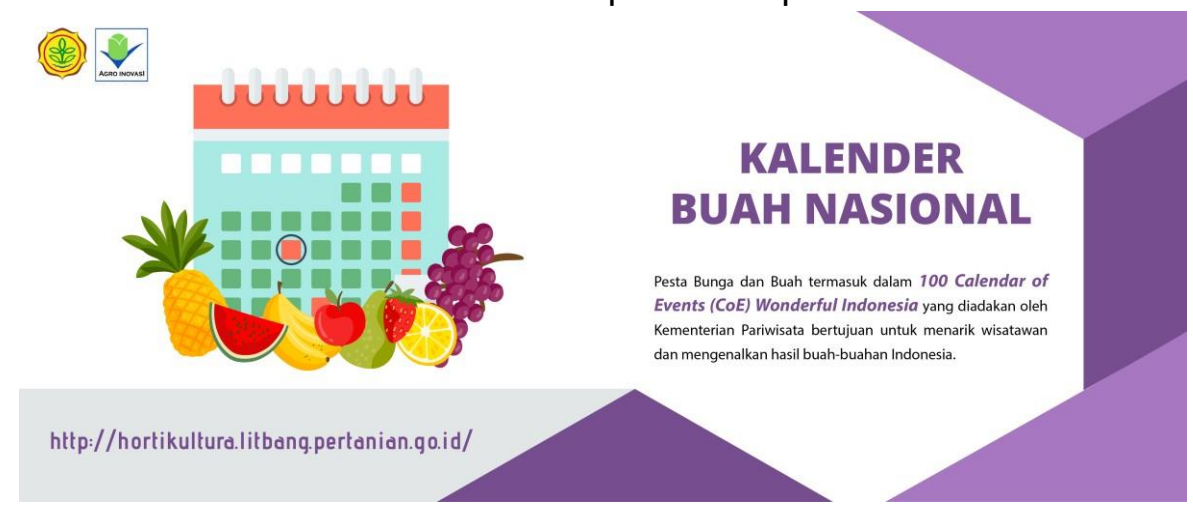

Gambar 7 Hasil Desain dan Implementasi Banner Web Kalender Buah Nasional

4. Pengujian 
Banner web yang telah dibuat kemudian dilakukan pengujian. Pengujian yang digunakan adalah pengujian alpha dan pengujian beta. Pengujian alpa atau alpha testing yaitu pengujian yang dilakukan oleh pihak internal sebelum didistribusikan kepada pihak eksternal. Pengujian alpha pada produk banner web ini dilakukan oleh pembimbing lapang dengan cara memastikan informasi yang disampaikan sudah benar dan foto yang ditampilkan sesuai dengan tema.

Kemudian pengujian beta atau beta testing yaitu pengujian yang dilakukan oleh pihak eksternal perusahaan. Pengujian beta dilakukan dengan cara membuat survei dengan pertanyaan yang menyangkut dengan informasi yang disampaikan dan warna yang digunakan pada banner web. Survei yang dibuat telah dinilai oleh 10 orang responden dengan menjawab pertanyaan dan memilih "Ya" atau "Tidak" serta memberikan saran pada banner web.

Kesimpulan hasil survei yang dilakukan berdasarkan informasi yang disampaikan pada banner web adalah $80 \%$ responden memilih "Ya" dan $20 \%$ responden memberikan saran tentang penggunaan typeface pada banner web. Pada komponen pemilihan warna yang digunakan, 100\% responden memilih "Ya" dan pada komponen kejelasan tulisan pada saat dibaca, $50 \%$ responden memilih "Ya" dan 50\% responden memilih "Tidak". Komponen terakhir yaitu penggunaan foto dapat mewakilkan informasi yang disampaikan menghasilkan $100 \%$ responden memilih "Ya". Dapat disimpulkan bahwa banner web yang dihasilkan sudah layak ditampilkan berdasarkan informasi, perpaduan warna, dan penggunaan foto.

\section{Hasil dan Pembahasan Video}

\subsection{Pra Produksi}

Tahap pra produksi adalah tahap awal persiapan segala kebutuhan sebelum memasuki tahapan produksi. Tahap ini memudahkan untuk tahapan selanjutnya yaitu produksi. Tahap produksi meliputi konsep, pengumpulan data, membuat naskah, dan membuat storyboard.

\subsubsection{Konsep}

Proses konsep adalah proses pembuatan gagasan atau ide yang akan diterapkan pada video yang akan dibuat. Konsep yang dibahas dalam pembuatan video ini bersifat simpel dan non formal agar audience tidak bosan melihat video yang ditampilkan. Diskusi konsep bertujuan untuk menentukan target audiens, durasi video, dan tujuan pembuatan video. Video company profile menampilkan profil Puslitbang Hortikultura seperti gedung, fasilitas, teknologi unggulan, jasa pelayanan, dan sumber daya manusia yang terdapat di Puslitbang Hortikultura.

\section{a. Target audiens}

Target utama pembuatan video ini ditujukan untuk pegawai Puslitbang Hortikultura dan masyarakat dengan rentang usia 16-60 tahun. Pemilihan rentang usia 16-60 tahun dikarenakan pada usia 16 tahun anak-anak sudah mulai mengenal gawai dan mendapat banyak informasi melalu gawai yang digunakan sehingga proses promosi dapat berjalan dengan baik. Pada usia 60 tahun adalah usia pegawai pada umumnya yang mulai memasuki masa pensiun sehingga 
informasi yang disampaikan masih cukup jelas untuk dibaca dan didengar.

\section{b. Durasi video}

Durasi video yang akan dihasilkan didiskusikan bersama pembimbing lapangan sesuai dengan konsep yang sudah ditentukan. Durasi untuk video company profile adalah 3-4 menit dengan ketentuan seluruh informasi Puslitbang Hortikultura tersampaikan.

\section{c. Tujuan}

Tujuan pembuatan video company profile yaitu dapat memberikan informasi tentang gedung, fasilitas, jasa pelayanan, sumber daya manusia, balai penelitian, serta informasi tentang Puslitbang Hortikultura lainnya.

\subsubsection{Pengumpulan Data}

Pengumpulan data bertujuan untuk memperkuat informasi yang disampaikan pada video. Pengumpulan data dilakukan pada saat berdiskusi dengan pembimbing lapang. Data yang dikumpulkan berupa powerpoint sekilas tentang Puslitbang Hortikultura yang berisi tentang informasi sejarah, sumber daya manusia, jasa pelayanan, produk unggulan, teknologi unggulan, dan kerjasama yang telah dilakukan, pengempulan foto yang akan ditampilkan dalam video seperti foto produk, foto kerjasama, dan foto event yang telah diadakan. Pengumpulan video pada Puslitbang Hortikultura yaitu menghasilkan satu buah video gedung Puslitbang Hortikultura yang diambil menggunakan drone, satu buah video gedung Balitbu Tropika, dan satu buah video kebun percobaan yang diambil menggunakan drone.

\subsubsection{Membuat Naskah}

Membuat naskah yang sesuai pada konsep yang telah dibahas sebelumnya dan ditentukan berdasarkan kesepakatan bersama antara pembimbing lapang dan Kepala Bidang Pendayagunaan Hasil Pertanian. Naskah dibuat sebagai acuan untuk membuat storyboard serta voice over sebagai penjelas video yang ditampilkan. Naskah yang dibuat menjelaskan tentang gedung, fasilitas, jasa pelayanan, sumber daya manusia, balai penelitian, kerjasama, serta informasi tentang Puslitbang Hortikultura lainnya.

\subsubsection{Membuat Storyboard}

Tahap selanjutnya adalah pembuatan storyboard. Storyboard merupakan rangkaian gambar sketsa yang menggambarkan alur cerita. Storyboard atau papan cerita adalah bentuk lanjutan dari naskah cerita yang sudah dikembangkan dan diimplementasikan dalam bentuk gambar.

\subsection{Produksi}

Tahap produksi pada video company profile meliputi pengambilan gambar atau video shooting sesuai dengan naskah, persiapan data atau footage preparation, pengambilan suara meliputi suara manusia dan musik latar, serta pemilihan typeface yang digunakan untuk infografis yang ditampilkan pada video. 


\subsubsection{Teknik Pengambilan Gambar}

Teknik pengambilan gambar pada video company profile adalah penerapan dari storyboard yang dibuat pada tahap pra produksi. Implementasi dari storyboard dapat dilihat pada Lampiran 2. Pengambilan gambar dilakukan selama lima hari dengan menyesuaikan lokasi pengambilan gambar. Teknik pengambilan gambar yang digunakan dalam pembuatan video company profile menggunakan tiga tiga jenis, yaitu :

\section{Type of Shot}

\section{a. Extreme close up}

Extreme close up menampilkan bagian khusus dari objek secara rinci dan detail. Teknik pengambilan gambar ini diimplementasikan pada video dengan memfokuskan pada objek pengatur suhu tanaman bawang.

b. Medium Close Up

Medium close up adalah pengambilan gambar dari bagian atas kepala sampai ke pinggang.

\section{Camera angle}

\section{a. Long Shot}

Long shot atau pengambilan jarak jauh, memperlihatkan keadaan objek secara keseluruhan,memantapkan semua elemen dalam gambar termasuk latar belakang (background) dan latar depan (forehead). Teknik pengambilan gambar ini diimplementasikan pada saat pengambilan gambar gedung dengan menggunakan drone.

\section{b. Normal Angle}

Normal angle yakni posisi kamera sejajar dengan ketinggian fokus objek yang diambil atau pandangan sebatas mata. Teknik pengambilan gambar ini diimplementasikan pada video dengan adegan aktor memanen bawang.

\section{c. Over The Shoulder}

Over the shoulder menampilkan kesan latar depan atau belakang, di mana kamera berada di belakang bahu salah satu pelaku dan bahu si pelaku tampak atau kelihatan dalam frame. Teknik pengambilan gambar ini diimplementasikan pada aktor yang melakukan kegiatan di depan komputer.

\section{d. Low Angle}

Low angle yakni posisi lebih rendah daripada objek yang diambil atau pandangan dari bawah. Teknik pengambilan gambar ini diimplementasikan pada plang Unit Pengelolaan Benih Sumber yang terdapat di salah satu balai penelitian Pusitbang Hortikultura.

\section{e. High Angle}

High angle yakni posisi kamera lebih tinggi dari objek yang diambil atau pengambilan dari suatu ketinggian. Teknik pengambilan gambar ini diimplementasikan untuk menampilkan kebun percobaan yang terdapat di salah 
satu balai penelitian Puslitbang Hortikultura.

\section{Pergerakan Kamera}

a. Pan Left

Pan left yaitu kamera digerakkan mendatar dari kanan ke kiri. Pergerakan kamera ini diimplementasikan pada video dengan menampilkan tanaman hias.

\section{b. Pan Right}

Pan right yaitu kamera digerakkan mendatar dari kiri ke kanan. Pergerakan kamera ini diiplementasikan pada video dengan menampilkan salah satu balai penelitian Pusltbang Hortikultura.

\section{c. Tilt Up}

Tilt up adalah kamera yang digerakkan vertikal dari bawah ke atas. Pergerakan kamera ini diimplementasikan pada video dengan menunjukkan struktur organisasi yang terdapat di Puslitbang Hortikultura.

\section{d. Tilt Down}

Tilt down adalah kamera yang digerakkan vertikal dari atas ke bawah. Pergerakan kamera ini diimplementasikan pada video dengan menampilkan benih tanaman anggrek.

\subsubsection{Pemilihan Musik Latar}

Musik yang digunakan dalam video ini adalah musik instrumental yang digunakan berdasarkan dengan alur video dan menyesuaikan dengan tempo scene yang ditampilkan. Musik instrumental yang digunakan yaitu Arrival by MBB. Backsound yang digunakan diunduh dari www.youtube.com dengan kata kunci audio library.

\subsubsection{Typeface}

Istilah typeface lebih mengarah pada bentuk atau desain huruf yang digunakan. Typeface yang digunakan pada video company profile adalah Geometr212 BkCn BT. Alasan dari penggunaan typeface tersebut karena typeface ini termasuk jenis font Sans Serif. Sans Serif adalah tipografi dari guratan garis sederhana dan tidak memiliki hiasan atau guratan kecil di ujung karakter. Penggunaan typeface ini disetujui oleh pembimbing lapang dengan alasan mudah terbaca dan terlihat simpel.

\subsection{Pasca Produksi}

Tahap pasca produksi merupakan tahap akhir dalam pembuatan video. Pada tahap ini video akan melalui proses editing yang sesuai dengan alur cerita pada storyboard yaitu meliputi aspek gambar dan suara, rendering yaitu proses mengubah file projek ke file yang dapat dijadikan ke media lain sesuai dengan format video yang diinginkan, penggandaan video, evaluasi oleh pembimbing lapangan, revisi, dan distribusi video kepada pembimbing lapangan dengan menggunakan media CD dan flashdisk. 
a. Olah digital video atau video editing

Video editing dilakukan menggunakan perangkat lunak Adobe Premiere Pro CC 2018. Tahap video editing dimulai dengan pemilihan stok video yang diambil pada tahap produksi dengan tujuan untuk menyesuaikan dengan alur cerita pada storyboard. Video yang dipilih lalu disusun pada timeline dan menyesuaikan stok video dengan tempo backsound yang dipilih pada tahap produksi dengan cara memotong setiap video menggunakan razor tool pada toolbox Adobe Premiere Pro CC 2018. Tahap olah digital video dapat dilihat pada Gambar 8.

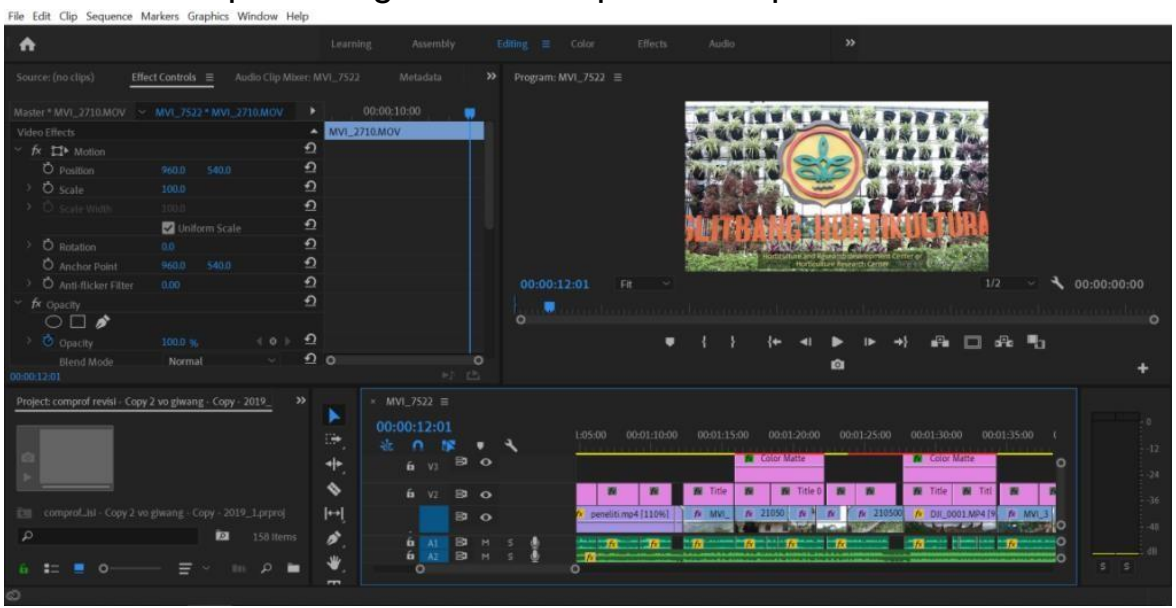

Gambar 8 Olah Digital Video

\section{b. Rendering}

Rendering video yaitu proses mengubah file projek menjadi sebuah file yang dapat dijalankan di media lain dengan format video pada umumnya. Proses rendering pada video company profile menghasilkan video berdurasi 3 menit 40 detik dengan ukuran resolusi layar FullHD yaitu 1920x1080 dan ekstensi file mp4. Proses rendering dilakukan pada perangkat lunak Adobe Premiere Pro CC 2018. Rendering dapat dilihat pada Gambar 9.

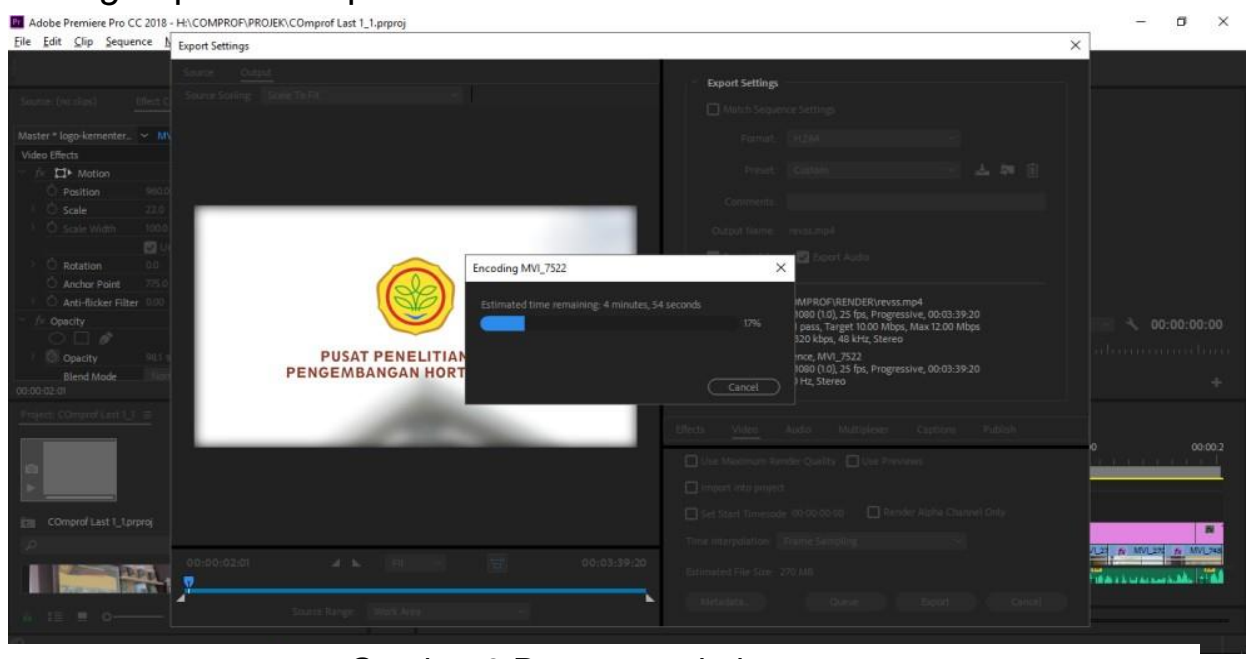

Gambar 9 Proses rendering

\section{c. Penggandaan Video}

Video yang telah selesai diolah pada proses rendering kemudian diduplikasi ke berbagai media yaitu DVD, flashdisk, dan harddisk. Video yang telah 
digandakan diserahkan kepada pembimbing lapang untuk dievaluasi.

\section{d. Evaluasi}

Menurut KBBI, evaluasi adalah proses untuk menemukan nilai layanan informasi atau produk sesuai dengan kebutuhan konsumen atau pengguna. Evaluasi pada video company profile ini dilakukan oleh pembimbing lapang. Evaluasi yang diberikan pembimbing lapang berupa evaluasi teknik editing, pengambilan suara, stok video yang digunakan, serta informasi yang disampaikan kurang tepat. Evaluasi yang didapat kemudian akan direvisi pada tahap selanjutnya.

\section{e. Revisi}

Revisi pada video company profile dilakukan berdasarkan dengan evaluasi yang telah diberikan oleh pembimbing lapang. Revisi yang diberikan pembimbing lapang berupa kritik dan saran. Kritik yang diberikan yaitu logo dan tulisan Puslitbang Hortikultura diawal video harus ditampilkan. Hasil revisi yang telah dilakukan akan didistribusikan kepada pembimbing lapang dan Kepala Bidang Kerjasama Pendayagunaan Hasil Pertanian.

\section{f. Distribusi}

Hasil video yang telah dievaluasi dan direvisi akan didistribusikan kepada pembimbing lapang. Video yang didistribusikan lalu dipublikasikan oleh pembimbing lapang pada front office Puslitbang Hortikultura.

\section{g. Pengujian}

Video yang telah dibuat kemudian dilakukan pengujian. Pengujian yang digunakan adalah pengujian alpha dan pengujian beta. Pengujian alpa atau alpha testing yaitu pengujian yang dilakukan oleh pihak internal sebelum didistribusikan kepada pihak eksternal. Pengujian alpha pada produk video company profile ini dilakukan oleh pembimbing lapang dengan cara memastikan informasi yang disampaikan sesuai dengan konsep yang telah didiskusikan sebelumnya.

Pengujian beta yaitu pengujian yang dilakukan oleh pihak eksternal perusahaan dengan cara membuat survei dengan pertanyaan yang menyangkut dengan informasi yang disampaikan serta visualisasi video sepeti audio dan teknik editing yang digunakan. Survei yang dibuat telah dinilai oleh 10 orang responden dengan menjawab pertanyaan serta memberikan saran pada video company profile.

Kesimpulan hasil survei yang dilakukan berdasarkan konsep pada video company profile adalah $100 \%$ responden memilih menarik. Pada komponen audio yang digunakan yaitu $80 \%$ responden memilih sangat jelas dan $20 \%$ responden memilih jelas serta pada komponen teknik editing yang digunakan, $80 \%$ responden memilih baik dan $20 \%$ responden memilih kurang baik. Pada komponen terakhir yaitu kejelasan informasi yang disampaikan menghasilkan $20 \%$ responden memilih sangat jelas dan $80 \%$ responden memilih jelas. Dapat disimpulkan bahwa video company profile yang dihasilkan sudah layak ditampilkan berdasarkan konsep, informasi, audio, dan editing. 


\section{SIMPULAN}

Kegiatan Praktik Kerja Lapang (PKL) di Puslitbang Hortikultura telah menghasilkan produk yang sudah melewati tahap evaluasi dan revisi. Produk yang dihasilkan berupa lima buah banner web dengan tema Analisis Kebijakan Hortikultura, Pengelolaan Tanaman Terpadu Cabai, Pengelolaan Tanaman Terpadu Bawang Merah, Asian Food and Agriculture Cooperation Initiative, dan Kalender Buah Nasional, serta menghasilkan satu buah video company profile Puslitbang Hortikultura. Produk tersebut dikerjakan berdasarkan metode bidang kajian yang dilakukan selama PKL. Tahapan pembuatan banner web dan video menggunakan dua metode, yaitu metode bidang kajian desain grafis dan metode bidang kajian video. Metode bidang kajian desain grafis meliputi konsep, pengumpulan bahan, desain dan implementasi, dan pengujian. Metode bidang kajian video meliputi pra produksi, produksi, dan pasca produksi.

Pembuatan produk ini diharapkan dapat meningkatkan daya tarik Puslitbang Hortikultura sebagai unit kerja Balitbangtan Kementerian Pertanian.

\section{SARAN}

Pembuatan banner web dan video sebagai media promosi di Pusat Penelitian dan Pengembangan Hortikultura masih memiliki beberapa kekurangan pada banner web dan video sehingga perlu adanya perbaikan. Produk ini dapat lebih baik lagi apabila didukung dengan perangkat keras dan perangkat lunak yang memiliki spesifikasi tinggi.

\section{DAFTAR PUSTAKA}

Brata, Vincent B.T. 2007. Videografi dan Sinematografi Praktis. Jakarta: PT Elex Media Komputindo.

Enterprise, Jubilee. 2018. Kitab Video Editing dan Efek Khusus. Jakarta: PT Elex Media Komputindo.

Enterprise, Jubilee. 2019. Belajar Sendiri Adobe Premiere Pro CC 2019. Jakarta: PT Elex Media Komputindo.

Hendratman, Hendi. 2017. The Magic Of Adobe Premiere Pro. Bandung: Informatika Bandung.

Komputer, Wahana. 2008. Video Editing dan Video Production. Jakarta: PT Elex Media Komputindo.

MADCOMS. 2009. Panduan Lengkap Editing Video dengan Adobe Premiere Pro.

Yogyakarta: C.V Andi Offset. 